"Mircea cel Batran" Naval Academy Scientific Bulletin, Volume XIX - 2016 - Issue 1

Published by "Mircea cel Batran" Naval Academy Press, Constanta, Romania // The journal is indexed in:

PROQUEST / DOAJ / DRJI / JOURNAL INDEX / I2OR / SCIENCE LIBRARY INDEX / Google Scholar / Crossref /

Academic Keys / ROAD Open Access / OAJI / Academic Resources / Scientific Indexing Services / SCIPIO

\title{
TEACHING MARITIME ENGLISH WITH DOODLES
}

\author{
Raluca APOSTOL-MATES ${ }^{1}$ \\ Alina BARBU ${ }^{2}$ \\ ${ }^{1}$ Junior Lecturer Ph.D. "Mircea cel Batran" Naval Academy, Constanța \\ ${ }^{2}$ Senior Lecturer Ph.D. Constanța Maritime University
}

\begin{abstract}
When it comes to acquiring new, specialized vocabulary like the lexis of Maritime English, it is well-nigh impossible to assert that this is a piece of cake. As a general rule, students of Maritime English get easily bored when being taught new words belonging to the maritime environment. Thus, any method which is liable to get them more motivated and appealed to the act of learning useful words is more than appropriate. Consequently, doodling comes in very handy as a learning tool given the fact that anybody makes use of it as a gesture of visual thinking. The present paper aims at presenting some very useful internet-based tools which students of Maritime English may employ in order to bring the verbal classroom to the visual classroom enhancing thereby their chance of becoming proficient in Maritime English.
\end{abstract}

Keywords: doodling, mind-mapping, visual thinking, mnemonic techniques, liminal thinking

\section{Introduction}

It is common knowledge that doodling while taking down notes may improve retention of new concepts, new vocabulary or new structures.

Despite the fact that many teachers are prone to discarding this approach without too much thinking about it, we have deemed proper to highlight the power of doodling as a learning tool in present-day EFL classes.

\section{Doodling Makes Learning Visible}

The premise is boredom proneness present in every student. From the point of view of cognitive psychology, boredom, besides being a very common experience, stimulates independent thinking and provides a paradoxical support for concentration.

Many students tend to instantly reject any task given feeling somewhat ordered around as if they were in the military. By asking them to doodle freely, encouraging them thereby to be absentminded actually brings about a surprising amount of recalled information of the material being taught while they were doodling.

Doodle may be used successfully to review or learn new vocabulary. Almost anyone has come across a visual puzzle at one time or another and found it appealing to decipher.

Well, doodles are much easier to sort out. First of all, they come in handy. One does not need to be an artist to draw a doodle in order to remember new vocabulary. In maritime English, students often find it extremely friendly both as a learning tool and a relaxing pastime.

As teachers of Maritime English, we have frequently resorted to doodling either purposefully or not. Students and teachers alike try their hand at sketching a ship in order to make it a useful visual aid for the upcoming test or exams.
One internet resource where one can easily use in order to do that is https://sketch.io/sketchpad/ or http://drawisland.com/.

Both these sites enable learners of any subject to acquire knowledge the fun way.

It goes without saying that one does not become a proficient visual communicator overnight. Everyone takes some practice in order to master a certain technique. Yet, there one undeniable fact, namely the worst and most hideous doodle may prove, at some time, to be useful.

Researchers have pointed out the fact that every time you get your scribbles down on paper, you are actually helping your brain to absorb information more effectively.

Providing you become good at doodling, you may easily evolve to mind pars which are extremely useful in the case of ESP students. For instance, when dealing with rather complicated issues such as The Parts of the Ship, teaching new vocabulary comes as a tremendous challenge for teachers and students alike. Doodles help by drawing a logical connection between the visual and the arid field of new lexis. Thus, teaching with visual aids such as the unjustly underrated doodles proves to be an innovative way to help students remember terminology. Examples may vary from personal sketches to elaborate mind maps.

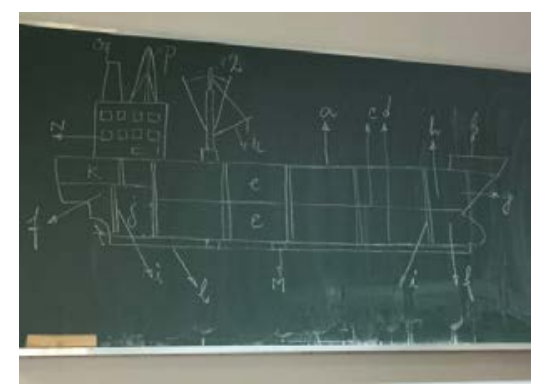


"Mircea cel Batran" Naval Academy Scientific Bulletin, Volume XIX - 2016 - Issue 1

Published by "Mircea cel Batran" Naval Academy Press, Constanta, Romania // The journal is indexed in: PROQUEST / DOAJ / DRJI / JOURNAL INDEX / I2OR / SCIENCE LIBRARY INDEX / Google Scholar / Crossref / Academic Keys / ROAD Open Access / OAJI / Academic Resources / Scientific Indexing Services / SCIPIO

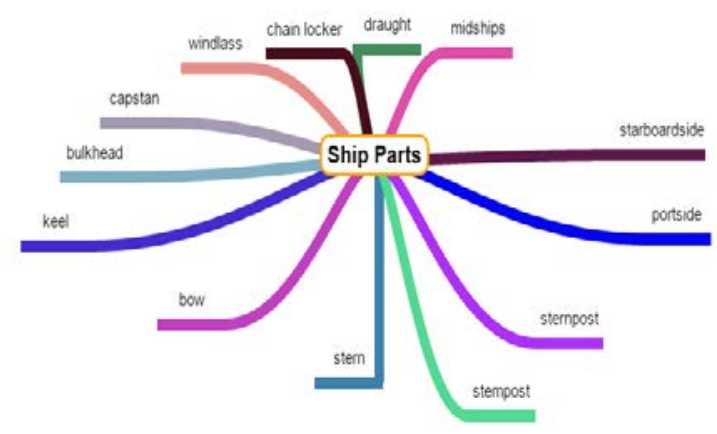

The following are online resources for any teacher interested in making use of doodles as a learning tool:

Dave Gray - Visual Thinker at http://xplaner.com/ provides an enlightening insight in visual thinking, culture mapping, and a 21-st century concept, liminal thinking. As far as the latter is concerned, the author Dave Gray (the godfather of visual thinking), recently published his book on the subject (2016, Rosenfeld Media). In his book, the author clearly states the purpose of luminal thinking, which, he claims, is the art of creating change by understanding, shaping, and reframing beliefs.

Sunni Brown - Visual Speaker at http://sunnibrown.com/ offers a wide range of activities aimed at translating concepts into words and pictures so that the audience remains with insights they will never forget.

Doodle Revolution - Join up! Can be found at http://sunnibrown.com/doodlerevolution/ where the author introduces the concept of visual literacy and promotes a doodle revolution. The campaign is starting from common sense and getting at neuroscience the author tries to prove that doodling is actually likely, if used strategically, to ignite the whole mind.

Viz Think - all you need to know about visual thinking at http://vizthink.com/.

According to Charlotte Hughes and Scott Asakawa, two researchers who published in 2014 an insightful paper on doodling called "Keep Calm and Doodle On" "To a teacher, seeing a student hunched over her notebook furiously writing is generally thought of as a good sign. Upon closer inspection, however, a teacher sometimes discovers that instead of writing down notes, the student's notebook is filled with small drawings. The content of these creations varies, but generally, this kind of drawing is known as "doodling." For a long time, doodling has been thought, at best, to be an idle and mindless activity. At worst, it has been seen as a significant distraction from the real work of learning. Interestingly, recent research has revealed that doodling may actually help the brain to process certain kinds of information. Furthermore, it is possible that encouraging students to doodle may actually increase their engagement and interest in educational subject matter."

\section{CONCLUSIONS}

Despite the fact that doodling has been seen unjustly as frivolous or mere entertainment, the concept of sketch noting has its roots in neuroscience research about ways to improve memory. When an idea or a concept is encapsulated in an image it automatically becomes brain-friendly as the brain is able to retain it with ease.

Doodling proves to be extremely helpful in teaching English for Special Purpose, especially Maritime English, as it enables students to create a personal visual pathway to learning new concepts or words. This ancient teaching strategy should be revived and rebranded as it will certainly facilitate access to learning.

It is a good method to help analyze the information received as it enables you to lay it out as a big picture.

Memory retention is by all means improved as doodling helps students visualize concepts or content and better understand the relations among sub-concepts.

Doodling is indeed a valuable learning and teaching tool that can help the teacher share ideas about the lesson visually. As Henri Matisse once said: "To draw is to make an idea precise".

\section{BIBLIOGRAPHY}

[1] Margulies, Nancy, Maal, Nusa, Mapping Inner Space: Learning and Teaching Visual Mapping, 2nd Edition, Published by Zephir Press, USA, 2002, pp. 48-52, 110-116,

[2] Sonneman, Milly, Beyond Words: A Guide to Drawing Out Ideas, Published by Ten Speed Press, USA, 1997

[3] Roam, Dan, The Back of the Napkin: Solving Problems and Selling Ideas with Pictures, Penguin Books, 2009

[4] Hanks Kurt, Belliston Larry, Rapid Viz: A New Method for the Rapid Visualization of Ideas, Published by Cengage Course Technology PTR, USA, 2006 
"Mircea cel Batran" Naval Academy Scientific Bulletin, Volume XIX - 2016 - Issue 1

Published by "Mircea cel Batran" Naval Academy Press, Constanta, Romania /I The journal is indexed in: PROQUEST I DOAJ / DRJI / JOURNAL INDEX I I2OR / SCIENCE LIBRARY INDEX / Google Scholar / Crossref I Academic Keys / ROAD Open Access / OAJI / Academic Resources / Scientific Indexing Services / SCIPIO

[5] http://braindoodles.net/

[6] http://www.edudemic.com/doodling-a-teachers-secret-weapon/

[7] http://www.pbs.org/wgbh/nova/blogs/education/2014/07/keep-calm-and-doodle-on/

[8] http://learning.blogs.nytimes.com/2015/09/24/skills-and-strategies-doodling-sketching-and-mind-mappingas-learning-tools/? $r=0$ 